\title{
Treatment of acute retrolental fibroplasia by cryopexy
}

\author{
I. BEN-SIRA, I. NISSENKORN, E. GRUNWALD, AND Y. YASSUR \\ From the Department of Ophthalmology, Beilinson Medical Center, \\ Tel-Aviv University Medical School, Petah-Tiqva, Israel
}

SUMMARY Fifteen to $20 \%$ of premature infants weighing below $1500 \mathrm{~g}$ develop variable degrees of acute retrolental fibroplasia (RLF). Approximately $5 \%$ of those infants who develop RLF can be expected to become blind. A prospective study was carried out to evaluate if early cryopexy can prevent this blindness. The study showed that, among 533 infants admitted to the neonatal intensive care unit between July 1976 and December 1978, 55 had some degree of active RLF. In 18 eyes of 9 infants in whom the retinopathy progressed beyond active stage II cryopexy treatment was applied to the avascular retina. In all the treated eyes the active retinopathy regressed, and there were no complications due to the procedure. The long-term follow-up showed that in 15 eyes there was good vision and that the remaining 3 eyes had some impairment of vision but were not blind. These results suggest that cryotherapy may prove useful in treating premature infants with RLF who show progression of their active stage, without the danger of further visual loss or complete blindness.

Retrolental fibroplasia (RLF) is still a persistent problem in spite of modern techniques of monitoring $\mathrm{PaO}_{2}$ levels. Since both the incidence and the severity of RLF are directly related to the degree of prematurity as manifested by low birthweight (see Tables $1,2)$, this disorder can be expected to become an even more serious problem with the increasing capability of preserving life in extremely small premature infants.

In the majority of infants with RLF there is a spontaneous regression of the active stages with a subsequent normal vision. It has been found, however, that about 5\% will become totally blind due to cicatricial RLF (Table 2). In addition, a certain number, as yet undetermined, will show other serious ocular abnormalities such as high myopia, vitreous traction, dragged retinal vessels, heterotopic macula, strabismus, and amblyopia. Late complications include peripheral retinal degeneration, retinoschisis, retinal tears, and retinal detachment.

Several authors ${ }^{1-3}$ have worked out grading systems for the classification of the various stages of acute and cicatricial RLF. Others ${ }^{4}$ have provided more understanding of the pathogenesis of the disease by their report on the use of fluorescein

Correspondence to Dr Y Yassur, Department of Ophthalmology, Beilinson Medical Center, Petah-Tiqva, Israel. angiography and the clinicopathological correlations derived from it. There are, however, only a few recent reports on the incidence, prevalence, and natural history of this disease, especially in premature babies with RLF weighing below $1500 \mathrm{~g}$ at birth.

Since RLF has characteristics which are common to other ischaemic retinopathies, it was only natural that methods of treating such retinopathies, such as photocoagulation and cryopexy, would be tried in its treatment as well. Conflicting results have been obtained by this approach, ${ }^{5-12}$ probably owing to the lack of clear indications as to the optimal time of treatment and the exact method to be used.

In July 1976 a prospective study was started on premature babies with acute RLF to see whether blindness could be prevented by giving cryopexy treatment to selected eyes judged to have an increased probability of developing severe cicatricial RLF. The results of Kingham's series ${ }^{12}$ encouraged us to report the preliminary results of this study even before data from controlled studies on large numbers of eyes are available, in order to demonstrate that cryopexy, if done early, may be not only harmless but better than no treatment or than treatment carried out only when the eyes reach active stage IV, as in Kingham's series. ${ }^{12}$ The purpose of this report is also to stress the direct relationship between low birth weight and the 
Table 1 Incidence of active retrolental fibroplasia and birthweight

\begin{tabular}{|c|c|c|c|c|c|c|}
\hline \multirow[b]{2}{*}{ Reference } & \multirow{2}{*}{$\begin{array}{l}\text { Total no. } \\
\text { preterm } \\
\text { infants }\end{array}$} & \multirow[b]{2}{*}{$\begin{array}{l}\% \text { with } \\
\text { acute RLF }\end{array}$} & \multicolumn{4}{|c|}{ Birth weight (in grams) } \\
\hline & & & $\begin{array}{l}500-1000 \\
\text { No. of } R L F\end{array}$ & $\begin{array}{l}1001-1500 \\
\text { No. of } R L F\end{array}$ & $\begin{array}{l}1501-2000 \\
\text { No. of } R L F\end{array}$ & $\begin{array}{l}2001-2500 \\
\text { No. of } R L F\end{array}$ \\
\hline Kinsey et al. ${ }^{14}$ & 719 & $10.6 \%$ & - & $86(36 \%)$ & & \\
\hline Johnson et al. ${ }^{13}$ & 176 & $18 \%$ & $8(75 \%)$ & $50(32 \%)$ & $52(17 \%)$ & $37(5 \%)$ \\
\hline Kingham $^{3}$ & 521 & $16 \%$ & Not reported & & & \\
\hline Majima $^{17}$ & 470 & $32.6 \%$ & Not reported & & & \\
\hline Present study & 533 & $10 \%$ & $31(61 \%)$ & $112(20.5 \%)$ & $209(5 \cdot 2 \%)$ & $68(1.5 \%)$ \\
\hline
\end{tabular}

Table 2 Severity of cicatricial RLF in relation to birth weight in previous studies

\begin{tabular}{|c|c|c|c|c|c|c|c|c|c|}
\hline Reference & $\begin{array}{l}\text { Total } \\
\text { no. } \\
\text { infants }\end{array}$ & $\begin{array}{l}\text { No. of } \\
\text { infants } \\
\text { with } \\
\text { active } \\
\text { RLF }\end{array}$ & $\begin{array}{l}\text { No. of } \\
\text { eyes with } \\
\text { cicatricial } \\
\text { RLF } \\
\text { from } \\
\text { total } \\
\text { infants }\end{array}$ & $\begin{array}{l}\text { No. of } \\
\text { eyes with } \\
\text { cicatricial } \\
\text { RLF grades } \\
\text { I-II from } \\
\text { infants with } \\
\text { active } R L F\end{array}$ & $\begin{array}{l}\text { Same } \\
\text { for } \\
\text { grade } \\
\text { III }\end{array}$ & $\begin{array}{l}\text { Same } \\
\text { for } \\
\text { grades } \\
I V-V\end{array}$ & $\begin{array}{l}\text { Infants } \\
\text { below } \\
1000 \mathrm{~g}\end{array}$ & $\begin{array}{l}\text { No. of } \\
\text { eyes with } \\
\text { cicatricial } \\
\text { RLF from } \\
\text { all infants } \\
\text { below } \\
1000 \mathrm{~g}\end{array}$ & Comments \\
\hline Kinsey et al. ${ }^{14}$ & 719 & $66(11 \%)^{* * *}$ & $27(4 \%)$ & $21(32 \%)$ & $3(5 \%)$ & $3(5 \%)$ & $86 *$ & $\begin{array}{l}34(20 \%)^{*} \\
17(20 \%)\end{array}$ & $\begin{array}{l}\text { Under } 1200 \mathrm{~g} \text { birthweight. } \\
10 \text { cases excluded because } \\
\text { of lack of data. } \\
1971\end{array}$ \\
\hline Gunn et al..$^{15}$ & & $?$ & - & $\overline{24}(34 \%)$ & $2(3 \%)$ & $\begin{array}{l}4(11 \%) \\
4(6 \%)\end{array}$ & $\begin{array}{l}18 \\
35\end{array}$ & $\begin{array}{l}4(11 \%) \\
15(43 \%)\end{array}$ & $\begin{array}{l}\text { Data from } 1962-71 \\
\text { Data from } 1972-6\end{array}$ \\
\hline Lempert $^{18}$ & 185 & $8(5 \%)$ & $17(5 \%)$ & $12(33 \%)$ & & $5(14 \%)$ & - & & $\begin{array}{l}\text { Estimate based on } 10 \% \\
\text { active RLF } 1975\end{array}$ \\
\hline Johnson et al..$^{13}$ & 176 & $33(19 \%)$ & & $19(29 \%)$ & & $2(3 \%)$ & 8 & & $1968-71$ \\
\hline $\begin{array}{l}\text { Shahinian and } \\
\text { Malachowsky }\end{array}$ & 375 & $12(3 \%)$ & $8(11 \%)$ & & & $8(11 \%)$ & & & $\begin{array}{l}\text { Estimate based on } 10 \% \\
\text { active RLF 1973-4 }\end{array}$ \\
\hline
\end{tabular}

occurrence and severity of RLF, the absence of long-term complications due to the treatment, and the absence of any blindness in the treated eyes.

\section{Materials and methods}

All of the 533 surviving premature babies admitted to the neonatal Intensive Care Unit of the Beilinson Medical Center between July 1976 and December 1978 were examined. The first indirect ophthalmoscopic examination was usually carried out at the age of 2 weeks, with a subsequent monthly examination up to the age of 6 months. Acute retrolental fibroplasia was diagnosed in 55 infants $(10 \%)$, who were then examined weekly. Eyes were considered to require treatment if serial examinations revealed progression of the retinopathy beyond active stage II according to Patz's classification. ${ }^{2}$ In the initial stages of this study only the worse eye was treated. However, 2-6 weeks later, when it was evident that there was an arrest of the active retinopathy in the treated eye and that no complication had occurred, the fellow eye was treated too, if it had also progressed beyond active stage II.

Cryopexy was performed under general anaesthesia with ketamine hydrochloride, with or without the use of an endotracheal tube. The conjunctiva was never incised and the muscles were never held by fixation forceps or fixation sutures. Under observation with an indirect ophthalmoscope a retinal cryoprobe was placed transconjunctivally over the peripheral avascular retina. The retina anterior to the neovascularisation tufts was treated, each location being frozen only once. No particular attempt was made to freeze the neovascular tufts themselves. No special postoperative treatment was applied.

\section{Results}

Among the 55 infants with active RLF the retinopathy never exceeded stage II in $46(84 \%)$, and eventually spontaneously regressed and healed. All 
the 9 infants in whom the active retinopathy started to progress beyond stage II and who were subjected to treatment weighed below $1500 \mathrm{~g}$ at birth. Three weighed between 1001 and 1500 and 6 weighed between 500 and $1000 \mathrm{~g}$ (Table 3). In these infants the temporal ridge was thick, and the neovascular

Table 3 Incidence and severity of active $R L F$ in relation to birthweight

\begin{tabular}{lllll}
\hline $\begin{array}{l}\text { Birthweight } \\
\text { in } g\end{array}$ & $\begin{array}{l}\text { No. } \\
\text { of } \\
\text { infants }\end{array}$ & $\begin{array}{l}\text { Infants } \\
\text { with } \\
\text { acute }\end{array}$ & $\begin{array}{l}\text { Active } \\
\text { RLF } \\
\text { exceeding } \\
\text { stage II } \\
\text { treated } \\
\text { cases }\end{array}$ & $\begin{array}{l}\% \text { of active } \text { RLF treated } \\
\% \text { of tol no. of infants }\end{array}$ \\
\hline $500-1000$ & 31 & $19(61.3 \%)$ & 6 & $\frac{32 \%}{19 \%}$ \\
$1001-1500$ & 112 & $23(20.5 \%)$ & 3 & $\frac{13 \%}{3 \%}$ \\
$1501-2000$ & 209 & $11(5 \cdot 2 \%)$ & - & - \\
$2001-2500$ & 68 & $1(1.5 \%)$ & - & - \\
$2500-$ & 113 & $1(0.9 \%)$ & - & - \\
Total & 533 & $55(10.3 \%)$ & 9 & $\frac{16 \%}{1.6 \%}$ \\
\hline
\end{tabular}

tufts were large and engorged. There was an elevated retinal neovascularisation and small to moderate vitreous haemorrhages. After ablative cryopexy over the avascular retina these 18 eyes showed a rapid arrest of the active retinopathy and started to heal.

No complications resulted from the cryoapplication. In all cases the slight conjunctival chemosis and lid swelling present postoperatively subsided within 2-3 days. None of the eyes progressed to more than cicatricial stage II. Fifteen of these treated eyes were later found to have macular fixation, and they were considered to have good vision. Of the other 3 eyes, 1 became highly myopic (case 7, Table 4) and 2 developed mildly displaced macula (case 1, Table 4).

\section{Discussion}

Only a few published reports provide precise data of the natural history of acute RLF (Table 2). It is generally accepted that the mild forms of RLF are reversible. It was noted in previous studies, as well as in ours, that the great majority of cases of acute RLF occur among infants of low birth weight, and that they are more severe. ${ }^{1314}$

Table 4 Relevant data on 18 eyes with retrolental fibroplasia

\begin{tabular}{|c|c|c|c|c|c|c|c|c|c|c|c|c|c|c|}
\hline Case & Eye & $\begin{array}{l}\text { Birth } \\
\text { weight } \\
(g)\end{array}$ & $\begin{array}{l}\text { Days } \\
\text { in } \\
\text { oxy- } \\
\text { gen }\end{array}$ & $\begin{array}{l}\mathrm{Max} \\
\mathrm{PaO}_{2}\end{array}$ & $\begin{array}{l}\text { Age } \\
\text { at } \\
\text { diag- } \\
\text { nosis } \\
\text { (weeks) }\end{array}$ & $\begin{array}{l}\text { Shape } \\
\text { of } \\
\text { active } \\
\text { RLF at } \\
\text { diag- } \\
\text { nosis }\end{array}$ & $\begin{array}{l}\text { Age } \\
\text { at } \\
\text { treat- } \\
\text { ment } \\
\text { (weeks) }\end{array}$ & $\begin{array}{l}\text { Optic } \\
\text { nerve } \\
\text { angle* }\end{array}$ & $\begin{array}{l}\text { Active } \\
\text { RLF } \\
\text { stage } \\
\text { at } \\
\text { treat- } \\
\text { ment }\end{array}$ & $\begin{array}{l}\text { Duration } \\
\text { of } \\
\text { follow-up }\end{array}$ & $\begin{array}{l}\text { RLF } \\
\text { stage } \\
\text { cicatri- } \\
\text { cial }\end{array}$ & $\begin{array}{l}\text { Optic } \\
\text { nerve } \\
\text { angle }\end{array}$ & Comments & $\begin{array}{l}\text { Ocular picture at } \\
\text { last examination }\end{array}$ \\
\hline 1 & $\begin{array}{l}\text { OD } \\
\text { OS }\end{array}$ & 800 & 4 & 120 & 7 & $\begin{array}{l}\text { II } \\
\text { II }\end{array}$ & $\begin{array}{r}9 \\
11\end{array}$ & $\begin{array}{r}100^{\circ} \\
75^{\circ}\end{array}$ & $\begin{array}{l}\text { III } \\
\text { III }\end{array}$ & 72 weeks & II & $\begin{array}{l}70^{\circ} \\
55^{\circ}\end{array}$ & $\begin{array}{l}\text { Good vision } \\
4.5 \text { sph. myop. }\end{array}$ & $\begin{array}{l}\text { Displaced macula } \\
\text { Displaced macula } \\
\text { Esotropia }\end{array}$ \\
\hline 2 & $\begin{array}{l}\text { OD } \\
\text { OS }\end{array}$ & 620 & 7 & 55 & 10 & I & $\begin{array}{l}13 \\
15\end{array}$ & $\begin{array}{l}120^{\circ} \\
120^{\circ}\end{array}$ & $\begin{array}{l}\text { II } \\
\text { III }\end{array}$ & 63 & $\begin{array}{l}\text { I } \\
\text { I-II }\end{array}$ & $\begin{array}{r}100^{\circ} \\
90^{\circ}\end{array}$ & $\begin{array}{l}\text { Good vision } \\
\text { Good vision }\end{array}$ & $\begin{array}{l}\text { Normal } \\
\text { Opaque mass in } \\
\text { periphery }\end{array}$ \\
\hline 3 & $\begin{array}{l}\text { OD } \\
\text { OS }\end{array}$ & 1080 & 8 & 64 & 12 & I & $\begin{array}{l}15 \\
16\end{array}$ & $\begin{array}{l}120^{\circ} \\
120^{\circ}\end{array}$ & $\begin{array}{l}\text { II-III } \\
\text { II-III }\end{array}$ & 45 & - & $\begin{array}{l}120^{\circ} \\
120^{\circ}\end{array}$ & $\begin{array}{l}\text { Good vision } \\
\text { Good vision }\end{array}$ & $\begin{array}{l}\text { Normal } \\
\text { Normal }\end{array}$ \\
\hline 4 & $\begin{array}{l}\text { OD } \\
\text { OS }\end{array}$ & 980 & 7 & 170 & 6 & I & 10 & $\begin{array}{l}100^{\circ} \\
100^{\circ}\end{array}$ & $\begin{array}{l}\text { III-IV } \\
\text { III-IV }\end{array}$ & 41 & I-II & $\begin{array}{l}100^{\circ} \\
110^{\circ}\end{array}$ & $\begin{array}{l}\text { Impaired vision } \\
\text { Good vision }\end{array}$ & $\begin{array}{l}\text { Macular changes } \\
\text { Normal macula }\end{array}$ \\
\hline 5 & $\begin{array}{l}\text { OD } \\
\text { OS }\end{array}$ & 750 & 1 & 66 & 10 & $\begin{array}{l}\text { I } \\
\text { I }\end{array}$ & $\begin{array}{l}13 \\
12\end{array}$ & $\begin{array}{l}90^{\circ} \\
90^{\circ}\end{array}$ & $\begin{array}{l}\text { II }+ \\
\text { III }\end{array}$ & 34 & $\begin{array}{l}\text { I } \\
\text { I }\end{array}$ & $\begin{array}{l}100^{\circ} \\
100^{\circ}\end{array}$ & $\begin{array}{l}\text { Good vision } \\
\text { Good vision }\end{array}$ & $\begin{array}{l}\text { Good macula } \\
\text { Good macula }\end{array}$ \\
\hline 6 & $\begin{array}{l}\text { OD } \\
\text { OS }\end{array}$ & 1140 & 1 & 130 & 3 & $\begin{array}{l}\text { II } \\
\text { I }\end{array}$ & $\begin{array}{l}9 \\
7\end{array}$ & $\begin{array}{l}100^{\circ} \\
100^{\circ}\end{array}$ & $\begin{array}{l}\text { III } \\
\text { III }\end{array}$ & 30 & - & $\begin{array}{l}110^{\circ} \\
110^{\circ}\end{array}$ & $\begin{array}{l}\text { Good vision } \\
\text { Good vision }\end{array}$ & $\begin{array}{l}\text { Good macula } \\
\text { Good macula }\end{array}$ \\
\hline 7 & $\begin{array}{l}\text { OD } \\
\text { OS }\end{array}$ & 900 & 3 & 79 & 7 & I & $\begin{array}{l}16 \\
16\end{array}$ & $\begin{array}{l}100^{\circ} \\
100^{\circ}\end{array}$ & $\begin{array}{l}\text { II-III } \\
\text { II-III }\end{array}$ & 30 & I & $\begin{array}{l}100^{\circ} \\
100^{\circ}\end{array}$ & $\begin{array}{l}\text { Good vision } \\
9.0 \text { sph. myop. }\end{array}$ & $\begin{array}{l}\text { Good macula } \\
\text { Good macula }\end{array}$ \\
\hline 8 & $\begin{array}{l}\text { OD } \\
\text { OS }\end{array}$ & 1430 & 30 & 185 & 6 & I & $\begin{array}{l}9 \\
9\end{array}$ & $\begin{array}{l}120^{\circ} \\
120^{\circ}\end{array}$ & $\begin{array}{l}\text { II-III } \\
\text { II-III }\end{array}$ & 28 & I & $\begin{array}{l}120^{\circ} \\
120^{\circ}\end{array}$ & $\begin{array}{l}\text { Good vision } \\
\text { Good vision }\end{array}$ & $\begin{array}{l}\text { Good macula } \\
\text { Good macula }\end{array}$ \\
\hline 9 & $\begin{array}{l}\text { OD } \\
\text { OS }\end{array}$ & 880 & 1 & 88 & 8 & I & $\begin{array}{l}15 \\
15\end{array}$ & $\begin{array}{l}120^{\circ} \\
120^{\circ}\end{array}$ & $\begin{array}{l}\text { II-III } \\
\text { II-III }\end{array}$ & 20 & - & $\begin{array}{l}120^{\circ} \\
120^{\circ}\end{array}$ & $\begin{array}{l}\text { Good vision } \\
\text { Good vision }\end{array}$ & $\begin{array}{l}\text { Good macula } \\
\text { Good macula }\end{array}$ \\
\hline
\end{tabular}

$\mathrm{OU}=$ both eyes. $\mathrm{OD}=$ right eye. $\mathrm{OS}=$ left eye. *Angle of main blood vessels emerging from the optic disc. 
Among the 533 premature infants studied by us there was an inverse relationship between the birth weight of the infant and the prevalence of acute RLF (see Table 4). It is of note that in the group of premature babies with a birth weight under $1000 \mathrm{~g}$ the prevalence of acute RLF was between 61 and $75 \%$ (Table 1), and generally the RLF changes were more advanced than in premature babies with RLF with birth weight above $1000 \mathrm{~g}$.

Few statistics have been reported on the results of cryopexy treatment. In the co-operative 5-year study on the natural history of RLF, ${ }^{14}$ which involved 5 central intensive neonatal care units, there were 66 infants with acute RLF, of whom 32 were between 1000 and $1200 \mathrm{~g}$ birth weight. Of these, 3 became blind due to grades IV and V cicatricial RLF, and 3 had grade III cicatricial RLF, both stages being compatible either with low sion or with legal blindness. Of the 35 premature babies weighing $500-1000 \mathrm{~g}$ at birth who were followed up at the Montreal Children's Hospital by Gunn et al. ${ }^{15} 15(43 \%)$ had cicatricial RLF; of these, $6(20 \%)$ children were blind, 10 other children (28\%) had high myopia, and 2 more had esotropia.

Since our findings, as well as those of other workers, indicate that the prevalence and severity of RLF are positively related to the degree of retinal prematurity, or in other words to the extent of the zone of avascular hypoxic retinal tissue, it may be assumed that the development of RLF is triggered, as are other ischaemic retinopathies, by a vasoformative substance produced in the ischaemic retina. The larger the stimulus in the area of the available ischaemic retina to produce this substance, the greater would be the vasoproliferation, and hence the greater would be the chance for occurrence of complications leading to cicatricial forms. As in other ischaemic retinopathies, destruction of ischaemic retina is believed to reduce the formation of vasoformative substance and consequently to cause an arrest of the disease.

Our results suggest that such a destruction is easily achieved with cryopexy. In each of the treated eyes there was a rapid resolution or regression of the acute RLF changes. We decided to treat the second eye when it was observed that during the 2-6 weeks of the follow-up period the untreated eye continued to deteriorate, while the previously treated eye showed good regression of the acute RLF.

No complications were encountered which could be attributed to the cryopexy. These findings are unlike those of Kingham, ${ }^{12}$ who, in an unrandomised treatment study, reported optic atrophy and severe forms of cicatricial retinopathy after cryoapplication. These different results may be attri- buted to the differences in the time of treatment, to the surgical technique, and to the location of the cryoapplications. In our mode of treatment we did not attempt to destroy directly the ridge or the neovascular fronds themselves, but applied the cryoprobe only to the avascular peripheral retina, an approach which did not necessitate incising the conjunctiva, pulling muscles, and applying an inevitably stronger pressure on the premature eye. Since we treated the peripheral avascular retina while it was still close to the choroid and not already highly detached, we were able to freeze it properly and by less extensive applications. When the retina is already highly detached, heavy cryoapplication over the sclera and choroid may increase leakage from the choroidal vessels and thus increase the exudative detachment.

In Kingham's report ${ }^{12}$ from a series of 101 premature babies of various birth weights, of whom 14 eyes were treated, there was $7 \%$ of blindness. We feel that if treatment is performed earlier the rate of blindness should be less, because the acute RLF does not progress to stage IV, a stage in which the chance of successful treatment is, as previously explained, smaller. For the later stages of active, as well as for cicatricial RLF, surgery with an external buckling procedure may be the best solution. ${ }^{16}$

In light of the above findings it is encouraging to report that in our preliminary treatment study there was not a single case of blindness among the 55 children with acute RLF, of whom 32 had a birth weight below $1000 \mathrm{~g}$, and none progressed beyond active stage III. These results indicate that cryotherapy used in the method described here is safe and effective in arresting acute RLF and in preventing the progress of the retinopathy towards the severe forms of active and hence cicatricial RLF. The question which remains open is which of the treated children would have had their disease spontaneously regress if left untreated. Since all the children were treated before they reached active stage IV, unlike those in Kingham's series, it is impossible to provide an answer to this question until better criteria for prediction are available.

We thank Dr S. Reisner, head of the Neonatal Unit, and Dr R. Krickler for their excellent co-operation during the study.

\section{References}

${ }^{1}$ Reese AB, King M, Owens WC. A classification of retrolental fibroplasia. Am J Ophthalmol 1953; 36: 1333-5.

${ }^{2}$ Patz A. Retrolental fibroplasia. Surv Ophthalmol 1969; 14: $1-29$.

${ }^{3}$ Kingham JD. Acute retrolental fibroplasia. Arch Ophthalmol 1977; 95 : 39-47. 
${ }^{4}$ Kushner BJ, Essner D, Cohen IJ, Flynn JT. Retrolental fibroplasia. II. Pathologic Correlation. Arch Ophthalmol 1977; 95: 29-38

${ }^{5}$ Ohima K, Ikui $\mathrm{H}$, Kano M. Clinical study and photocoagulation of retinopathy of prematurity. Folia Ophthalmol Jpn 1971; 22: 700-8.

${ }^{6}$ Nagata M, Tsuruoka $\mathrm{Y}$. Treatment of acute retrolental fibroplasia with xenon arc photocoagulation. Jpn J Ophthalmol 1972; 16: 131-43.

'Payne JW, Patz A. Treatment of acute proliferative retrolental fibroplasia. Trans Am Acad Ophthalmol Otolaryngol 1972; 76: 1234-46.

${ }^{8}$ Kemura Y. Diagnosis and treatment of retinopathy of prematurity. Folia Ophthalmol Jpn 1975; 26: 1286-97.

'Sasaki K, Yamashita Y, Mackawa T, Adachi T. Treatment of retinopathy of prematurity in active stage of cryocautery. Jpn J Ophthalmol 1976; 20: 384-95.

${ }^{10}$ Tsumura R, Maruyama S, Ochi H. Ophthalmic care of premature infants. Folia Ophthalmol Jpn 1976; 27: 91-9.

${ }^{11}$ Yoshida M, Yoshida H, Amemiya A. A study on retinopathy of prematurity. Acta Soc Ophthalmol Jpn 1976; 79: $420-6$.
${ }^{12} \mathrm{Kingham}$ JD. Acute retrolental fibroplasia. II. Treatment by cryosurgery. Arch Ophthalmol 1978; 96: 2049-53.

${ }^{13}$ Johnson L, Schaffer D, Boggs TR. The premature infant, vitamin $\mathrm{E}$ deficiency and retrolental fibroplasia. $A m J$ Clin Nutr 1974; 27: 1158-73.

${ }^{14}$ Kinsey VE, Arnold $\mathrm{HJ}$, Kalina RE, et al. Pao, levels and retrolental fibroplasia: a report of the cooperative study. Pediatrics 1977; 60: 655-68.

${ }^{15}$ Gunn TR, Aranda JV, Little J. Incidence of retrolental fibroplasia. Lancet 1978; i: 216-7.

${ }^{16}$ Yassur Y, Grunwald E, Ben-Sira I. Surgical treatment of retrolental fibroplasia in infants. Metabol Ophthalmol 1978; 2: 333-4.

${ }^{17}$ Majima A. Studies on retinopathy of prematurity. I. Statistical analysis of factors related to occurrence and progression in active phase. Jpn J Ophthalmol 1977; 21: 404-20.

${ }^{18}$ Lempert P. Retrolental fibroplasia: Detection and incidence. Metabol Ophthalmol 1978; 2 : 331-2.

${ }^{19}$ Shahinian L, Malachowsky N. Retrolental fibroplasia-a new analysis of risk factors based on recent cases. Arch Ophthalmol 1978; 96: 70-4. 